\title{
Epidermodysplasia Verruciformis
}

National Cancer Institute

\section{Source}

National Cancer Institute. Epidermodysplasia Verruciformis. NCI Thesaurus. Code

C126877.

An extremely rare skin disorder usually inherited in an autosomal recessive pattern and caused by mutation(s) in the TMC6 or TMC8 gene, encoding transmembrane channellike protein 6 and transmembrane channel-like protein 8 , respectively. It is characterized by chronic human papillomavirus infection. Patients develop papillomatous wart-like lesions and pigmented plaques on the skin. It predisposes to cutaneous carcinomas, especially in situ and invasive squamous cell carcinomas. 